\title{
Foraging by mobile predators on a rocky shore: underwater TV observations of movements of blennies Lipophrys pholis and crabs Carcinus maenas
}

\author{
Michael T. Burrows ${ }^{1, *}$, Kei Kawai $^{2}$, Roger N. Hughes $^{2}$ \\ ${ }^{1}$ Dunstaffnage Marine Laboratory, Centre for Coastal Marine Sciences, PO Box 3, Oban PA34 4AD, United Kingdom \\ ${ }^{2}$ School of Animal Biology, University of Wales, Bangor LL57 2UW, United Kingdom
}

\begin{abstract}
The hypothesis was proposed that shore fishes and crabs, predators other than gastropods, may be primarily responsible for depletion of barnacle populations in the vicinity of crevices through thigmotactic behaviour during foraging. To test this hypothesis, movements of mobile predators on barnacle-dominated rock in the lower intertidal zone were observed using a fixed underwater television camera. An area of $0.2 \mathrm{~m}^{2}$ was monitored continuously for $14 \mathrm{~d}$ on a vertically oriented but relatively protected shore on the west coast of Scotland. Infrared lights during nighttime high tides lit the area. Stereo photography was used to determine the topography of the area. The principal species seen by day was the blenny Lipophrys pholis (L.) while the shore crab Carcinus maenas (L.) was the most frequent species at night. Scorpion fish Taurulus bubalis (Euphrasen), dogwhelks Nucella lapillus (L.) and a single North American mink Mustela vison Schreber were also seen. Movements of crabs, and especially blennies, were concentrated around small-scale concavities in the rock surface of less than $10 \mathrm{~cm}$ dimensions, supporting the primary hypothesis. Times spent by Lipophrys pholis and Carcinus maenas in $0.001 \mathrm{~m}^{2}\left(10 \mathrm{~cm}^{2}\right)$ areas within the video frame varied by 3 and 2 orders of magnitude, respectively. These 2 species are known to be active predators of barnacles Semibalanus balanoides and showed behaviour consistent with attacks on barnacles as prey. Observed movements and apparent spatial concentration of attacks, especially around crevices, may be a cause of patchiness in barnacle populations at this scale.
\end{abstract}

KEY WORDS: Rocky shores · Predation - Barnacles $\cdot$ Crabs - Intertidal fishes $\cdot$ Surface topography

\section{INTRODUCTION}

Predation has been long recognised as a major process structuring rocky shore communities (Fischer-Piette 1935, Connell 1961). Keystone predator species may prevent primary competitors among the sessile species from dominating the community in some areas (Paine 1966). Elsewhere predators may either determine lower limits of sedentary animals (Connell 1970) or simply reduce their overall abundance (Fairweather et al. 1984).

Analyses of spatial variation in rocky shore communities on a range of scales have shown that 2 peaks

•E-mail: mtb@wpo.nerc.ac.uk occur in the spectra of variation: at scales of several metres or less and at larger scales of several kilometres or more (Archambault \& Bourget 1996, Underwood \& Chapman 1996). Small-scale variation may be entirely generated by biological self-organisation, such as that produced by natural aggregations of limpet grazers on patches of fucoid macroalgae (Hartnoll \& Hawkins 1985, Johnson et al. 1997, Burrows \& Hawkins 1998), or the attraction of settling larvae to their conspecifics (Crisp \& Meadows 1962). The directly damaging effects of extreme wave action or wave-borne objects (Paine \& Levin 1981, Shanks \& Wright 1986) may physically generate it. The topography of the substratum itself generates a range of patchily distributed microhabitats that affect the growth and survival of inter- 


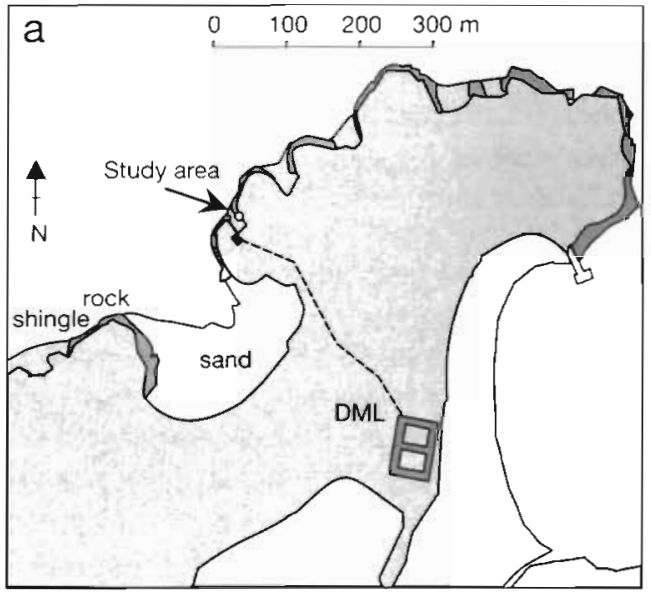

tidal organisms and thence community structure (e.g. Wethey 1984).

Behavioural responses of predators to the topography of the substratum (Kostlyev 1996) may be a major source of spatial variation in rocky shore communities. Mobile predators retreat to refuges such as crevices in the rock during harsh conditions of desiccation or wave action (Emlen 1966, Burrows \& Hughes 1989). Haloes of bare space or reduced population density may appear around refuges used by predatory gastropods (Seed 1969, Fairweather 1988, Hughes \& Burrows 1993), while large prey of sizes preferred by predators (Dunkin \& Hughes 1984) may also be reduced in number around such crevices (Johnson et al. 1998). The reduction in barnacle populations around crevices usually has been assumed to be caused by the activity of predatory gastropods such as dogwhelks Nucella lapillus (Hughes \& Burrows 1993, Johnson et al. 1998). Yet blennies Lipophrys pholis are known also to feed extensively on barnacle cirri (Qasim 1957), show thigmotactic movements (to increase the quantity of contact stimulation) and learn routes in rock pools and laboratory aquaria (Almada et al. 1983, Dodd 1998). To a lesser extent shore crabs Carcinus maenas are also known to take barnacles (Elner 1981) and show thigmotactic behaviour in laboratory tanks. If these observed patterns of movement are expressed during foraging in natural conditions, both species are good candidates for additional, and potentially more important, contributors to localised depletion of barnacle populations. This study, therefore, was designed to test the hypothesis that predators other than dogwhelks, specifically L. pholis and C. maenas, may be responsible for depletion of barnacle populations in the vicinity of crevices through thigmotactic behaviour during foraging. To test this hypothesis, intertidal predators (including blennies $L$. pholis and shore crabs C. maenas) were observed directly on a rocky shore using a video camera both in and out of water in a $0.2 \mathrm{~m}^{2}$ area
Fig. 1. (a) Map of the study site near Dunstaffnage Marine Laboratory (DML) and (b) schematic diagram of the positioning of the underwater camera in relation to the intertidal biota

over many diel and tidal cycles. Small-scale spatial variation in habitat selection by predators was quantified in relation to surface topography to test for the predicted positive relationship between frequency of visits and surface indentations. The presence of such relationships suggests the further hypothesis that topographically determined patterns of predation give rise to much of the small-scale patchiness in prey populations on rocky shores.

Long-term observations of movements allow the measurement of temporal patterns of behaviour over tidal, diel and longer-term time scales (Burrows et al. 1994). The second major aim of the study was to elucidate these patterns in the most common species of large mobile predators.

\section{METHODS}

Study site. The study site was a westerly facing rocky shore less than $0.5 \mathrm{~km}$ from the Dunstaffnage Marine Laboratory on the west coast of Scotland (Fig. 1). Although directly open to the prevailing southwesterly wind, the site is in the relatively protected waters of the Firth of Lorn, sheltered from oceanic swell by the islands of the Inner and Outer Hebrides. An area of approximately 0.5 by $0.4 \mathrm{~m}$ was selected for video surveillance on a vertical rock wall beside a cobble-filled cove. The square was between mean low water neaps $(1.8 \mathrm{~m})$ and mid-tide level $(2.4 \mathrm{~m}$ above Chart Datum) in a broad zone dominated by the barnacle Semibalanus balanoides extending from just above mean low water springs $(0.7 \mathrm{~m})$ to mean high water springs $(4.0 \mathrm{~m})$ (Fig. 1). A deep crevice in close proximity provided likely shelter for larger mobile predators, while the vertical surface ensured a short, direct path for subtidal predators during periods of inundation.

Underwater television observations. An underwater television camera (UWTV) (OE1390, Simrad Osprey Ltd) was mounted on a trapezoidal frame measuring $1.15 \mathrm{~m}$ along the base and $1.05 \mathrm{~m}$ from base to apex (Fig. 1). The frame was balanced on its side on a 
horizontal ledge, secured in position with sandbags filled with large cobbles, and oriented such that the camera pointed horizontally at the vertical rock surface. The scene was lit at night when the tide was in by two $300 \mathrm{~W}$ underwater lights (Osprey OE1132) fitted with infrared filters. A combined cable connected the camera and lights to a control unit (Osprey camera controller OE1230A) in a nearby building that housed pumps supplying seawater to the laboratory. Timelapse video recordings were made at 5.56 frames $\mathrm{s}^{-1}$ (Panasonic AG6024) after adding a time code signal (IMP Electronics time code generator V9000A). This gave $24 \mathrm{~h}$ of recording on $2 \mathrm{~h} 40 \mathrm{~min}$ of videotape.

Video recordings were made continuously for $14 \mathrm{~d}$ from low water at 12:20 h BST on 20 August until low water at 12:30 h BST on 3 September 1997.

Measurement and analysis of patterns of movement. Movements of large mobile epibenthic predators were recorded by digitising their location at the beginning and end of every move and at the end of each straight-line section of the trajectory while moving, for the whole period that they were visible. Co-ordinates were recorded using a computer program that logged the location of a pointer on the screen overlying the TV image. The time (to the nearest $0.01 \mathrm{~s}$ ) at each location was logged by the same program via a time code reader linked to the computer (VMR V9, IMP Electronics Ltd).

For 7 out of $14 \mathrm{~d}$ of recordings, the movements of every epibenthic animal passing the camera were quantified in detail. Three species were regularly seen: 2 fishes, the blenny Lipophrys pholis (Linnaeus 1758) and the sea scorpion Taurulus bubalis (Euphrasen 1786), and 1 crustacean, the shore crab Carcinus maenas, Linnaeus. Other species seen but not recorded included the two-spot goby Gobiusculus flavescens (Fabricius 1779) swimming in small shoals away from the rock surface during daylight hours, and a single North American mink Mustela vison (Schreber) handling dogwhelks Nucella lapillus (L.) at low water one afternoon. Mink are well established in Argyll following escapes from fur farms (Craik 1997). Dogwhelks and limpets Patella vulgata (L.) were also seen but their movements were not recorded for this study. Shore crabs and blennies were by far the most abundant species. Most subsequent analyses were of the movements of these 2 species.

Several measures of behaviour were derived from the sequences, after correction of the co-ordinates for distance from the camera and rotation relative to the vertical (see next section). The measures included the total duration of time visible, total distance moved, average speed, number of stationary pauses and the proportion of time spent paused. Directions of movement were calculated relative to the vertical, and changes in direction were recorded as the difference in angles of current and previous moves. The degree of convolution of the trajectory was measured as the ratio of the total distance moved to the straight-line distance from the point of entry to the point of exit from the field of view.

The frequency of occurrence and behaviour of Carcinus maenas, Lipophrys pholis and Taurulus bubalis were analysed in several ways. At the level of individual moves, distributions of distances travelled, time spent paused, and directions of movement were described and compared among species. Frequency of occurrence and measures of behaviour at the level of whole sequences were compared for each species among different dates, hours of the day 100:00 to 23:00 h) and time in hours relative to the nearest high water ( $6 \mathrm{~h}$ before to $6 \mathrm{~h}$ after high water). Non-parametric analysis of variance based on the ranks of the data was used to test the significance of observed patterns. Finally, the spatial distribution of behaviour was examined by plots of the measured trajectories and comparison of frequency of occurrence and measures of behaviour among different regions in the original camera view.

Topography of study area: depth, rotation and scaling of measured co-ordinates. The location of the camera frame was chosen for the best compromise of stability and a good field of view. The resulting image was rotated to the left of the vertical, with the furthest parts of the image (bottom right, Fig. 2a,b) approximately $1.2 \mathrm{~m}$ from the camera and the closest parts $0.6 \mathrm{~m}$ away (top left). Estimation of distances travelled in contact with the surface from the projected image in the TV picture therefore would be biased by these differences in distance from the camera, so correction for these effects was necessary.

Topography of the surface was quantified using measurements from a stereo pair of photographs taken with the left image at the location of the TV camera (Fig. 2c). Distance from the plane $\left(z_{p}, \mathrm{~cm}\right)$ and co-ordinates along the plane of the cameras $\left(x_{p}, y_{p}, c m\right)$ were calculated using the method of van Rooj \& Videler (1996) such that:

$$
\begin{aligned}
& z_{\mathrm{P}}=\frac{z_{\mathrm{F}} \cdot x_{\mathrm{C}}}{x_{\mathrm{L}}-x_{\mathrm{R}}} \\
& x_{\mathrm{P}}=\frac{x_{\mathrm{L}} \cdot z_{\mathrm{P}}}{z_{\mathrm{F}}} \\
& y_{\mathrm{P}}=\frac{y_{\mathrm{L}} \cdot z_{\mathrm{P}}}{z_{\mathrm{F}}}
\end{aligned}
$$

where $Z_{\mathrm{F}}$ was the distance from the camera lens to the film plane $(38 \mathrm{~mm}), X_{C}$ was the separation distance of the 2 camera lenses $(22.5 \mathrm{~cm})$, while $\left(x_{L}, y_{L}\right)$ and $\left(x_{R}, y_{R}\right)$ were the co-ordinates of the same feature in left-hand and right-hand images, respectively.

Registration of the left-hand stereo image and the TV image was achieved by digitizing co-ordinates of 


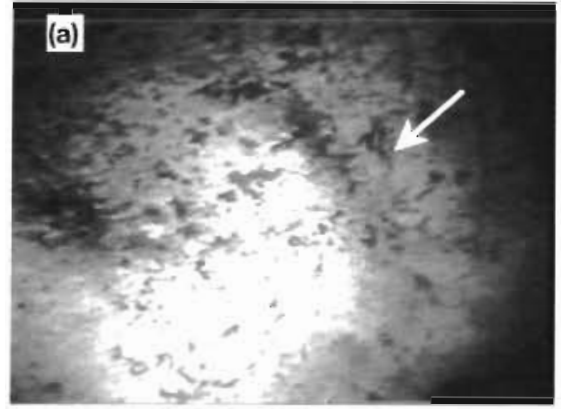

(c)

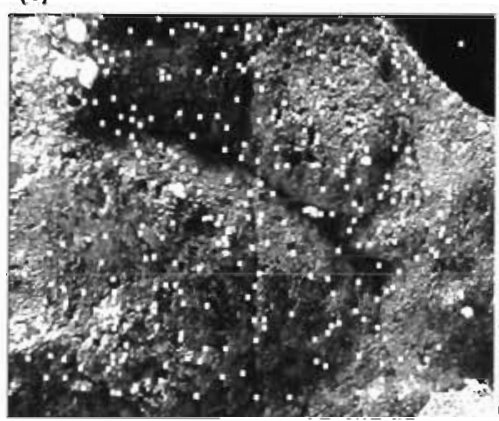

(e)

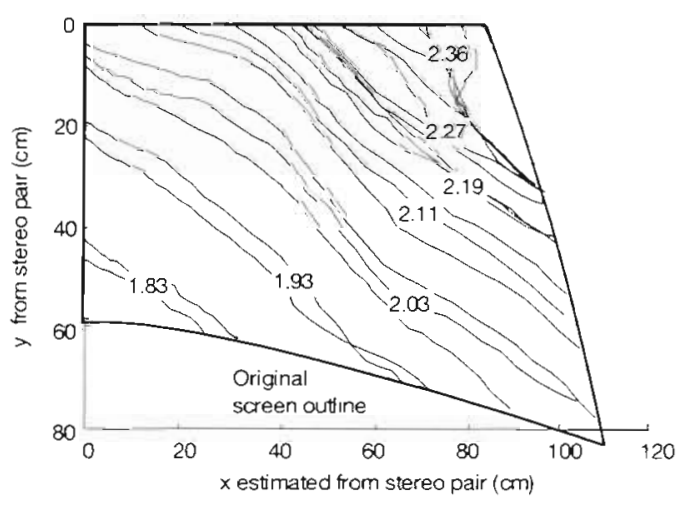

(g)

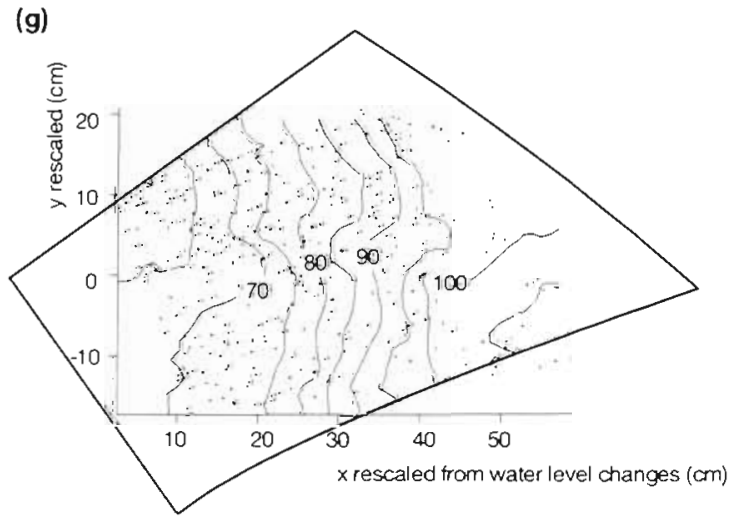

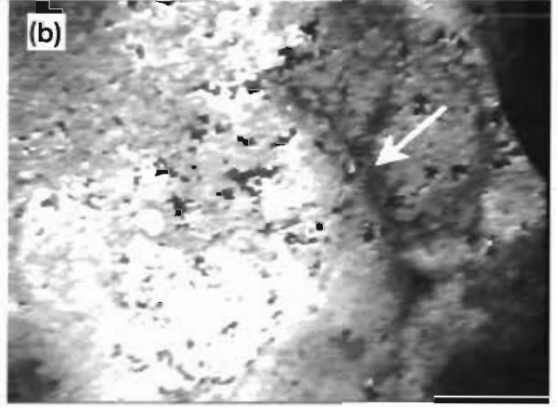

(d)
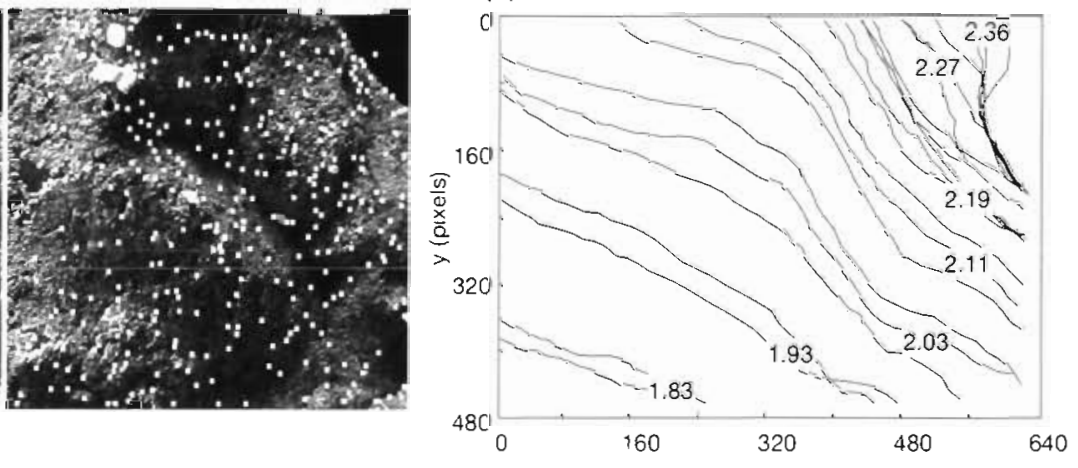

(f)

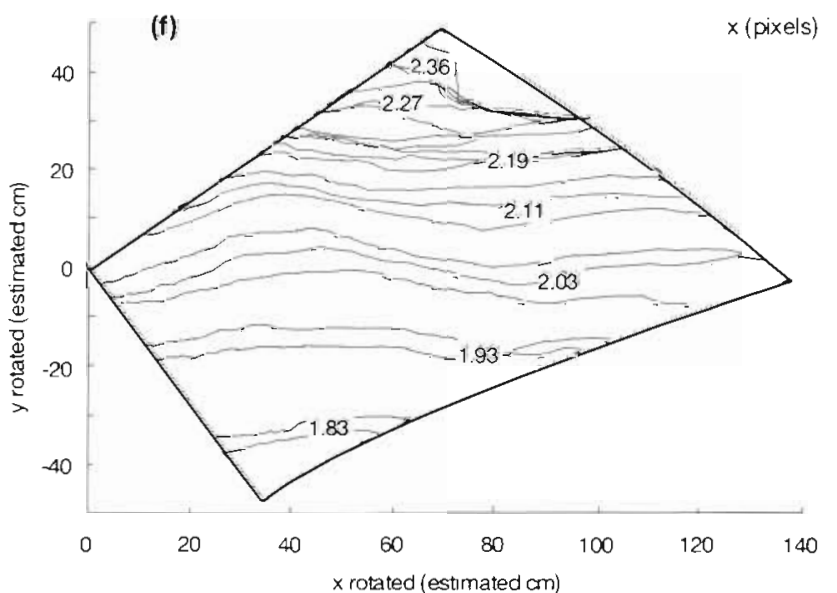

(h)

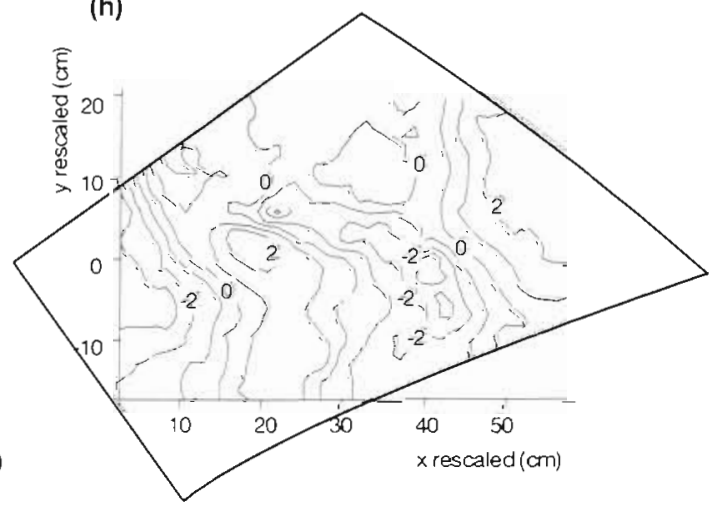

Fig. 2. Topography of the study area. Video images show the area covered by the tide with (a) a single Carcinus maenas at night (arrowed) and (b) a Lipophrys pholis by day (arrowed). (c) Paired co-ordinates of points in left-hand and right-hand images of a stereo pair. (d) Traces of the water surface in video images at $10 \mathrm{~min}$ intervals on a rising tide with calculated water heights (m above Chart Datum). (e) Water surface traces and image limits after correction for distance from the camera (see 'Methods' for details), and (f) rotation of co-ordinates to the vertical. (g) Contour plot of the estimated distance of the rock surface from the camera $(2 \mathrm{co}$-ordinate in $\mathrm{cm}$ ) with the location, and $(\mathrm{h})$ residuals from a fitted smooth response surface (as $\mathrm{cm}$ above or below) as a measure of small-scale topography 
the same features in each image. Co-ordinates on the left-hand stereo image were nearly perfectly registered to those on the TV image by rotation around a centre of rotation (to the right by 0.47 radians around $x=168, y=470$ ), and re-scaling to match the $640-480$ pixel dimensions of the TV image.

This procedure produced measures of the distance from the camera of a large number of points within the view of the TV camera (Fig. 2c, g). To estimate the distance from the camera of any object in the camera view, the relationship between measured distance $\left(z_{\mathrm{p}}\right)$ and position within the image $\left(x_{T V}, y_{T V}\right)$ was determined by stepwise polynomial regression. Parameters from the best-fit model were used to predict distances from the camera for all digitised positions of predators. These predicted distances $\left(\hat{z}_{\mathrm{p}}\right)$ were then used in turn to predict co-ordinates along the plane of the cameras $\left(\hat{x}_{P}, \hat{y}_{P}, \mathrm{~cm}\right)$ using Eqs. (2) \& (3). Residuals of measured distances from those predicted by the fitted regression $\left(z_{\mathrm{p}}-\hat{z}_{\mathrm{p}}\right.$, Fig. $\left.2 \mathrm{~h}\right)$ gave the small-scale topographical structure of the rock surface.

The rotation of the TV image relative to the vertical plane was measured by observation of changing water levels over a $90 \mathrm{~min}$ period on a rising tide in calm weather between 07:30 and 09:00 h on 25 August 1997. Water levels were digitized from TV images every 10 min. A common slope relating water elevation (recalculated $\hat{y}_{P}$ ) to $x$ co-ordinates for these water levels $\left(\hat{x}_{\mathrm{P}} \mathrm{cm}\right)$ was obtained from linear regression as -0.732 , equivalent to a rotation of 0.632 radians (Fig. 2f) to the right of the vertical axis. All calculated co-ordinates of locations $\left(\hat{x}_{\mathrm{P}}, \hat{y}_{\mathrm{P}}\right)$ were therefore rotated by -0.632 about the origin at the top left-hand corner of the image (Fig. 2e,f).

As a check on the scale, observed water levels were compared to those predicted at $10 \mathrm{~min}$ intervals for the nearest standard port (Oban, $<4 \mathrm{~km}$ distant) using a tidal prediction program (POLTIPS for Windows v1.0, Proudman Oceanographic Laboratory 1996). Predicted and observed values were very highly correlated $\left(\mathrm{R}^{2}=\right.$
$0.985)$ and showed that original estimates of planar $x$ and $y$ co-ordinates were 1.62 times greater than their true values (Fig. 2f). This error may have been due to an unreliable estimate of the focal length of the TV camera, $Z_{F}$, relative to the size of the image.

\section{RESULTS}

\section{Observed behaviour}

Sequences of movement of crabs, blennies and scorpion fish were characterised by the appearance of the animal, a series of moves across the rock surface, sometimes punctuated by stationary pauses, followed by the exit of the animal from the field of view (Fig. 3). Apart from gross movements, some types of behaviour could be observed while the animals were visible. Carcinus maenas spent much time apparently feeding, picking over the rock surface with the chelae, although the food items manipulated could rarely be seen. In one instance, a single $C$. maenas removed 15 dogwhelks Nucella lapillus from an aggregation on the rock surface between $02: 15$ and $02: 48$ h on 28 August 1997 manipulating each one before dropping it. The success of these attacks could not be determined. Lipophrys pholis showed sequences of moves that were possibly attacks on barnacles. The fishes initially fixated on an area and oriented towards it; this was followed by a rapid dart towards the region. This sequence of events was often immediately followed by a twisting of the body, perhaps associated with biting off barnacle cirri. Restricted visibility during periods of wave action, uneven illumination during nighttime tides and the small size of the animals in the image (Fig. 2a,b) all prevented adequate measurement of these behavioural acts.

The locations of the animals could, however, always be seen. Sequences were divided into straight-line segments ('moves', Table 1 ) by the observer. Moves of

Table 1. Summary and statistical comparison of properties of behavioural sequences among the 3 species observed. Pn time $=$ proportion of time

\begin{tabular}{|c|c|c|c|c|c|c|c|}
\hline Species & $\mathrm{n}$ & $\begin{array}{l}\text { Median no. } \\
\text { of moves }\end{array}$ & $\begin{array}{l}\text { Median } \\
\text { duration }\end{array}$ & $\begin{array}{l}\text { Median dis- } \\
\text { tance travelled }\end{array}$ & $\begin{array}{l}\text { Median pn } \\
\text { time paused }\end{array}$ & $\begin{array}{l}\text { Median } \\
\text { speed }\end{array}$ & $\begin{array}{l}\text { Median convo- } \\
\text { lution of path }\end{array}$ \\
\hline $\begin{array}{l}\text { Shore crab } \\
\text { Carcinus maenas }\end{array}$ & 200 & 16 & $81.3 \mathrm{~s}$ & $48.0 \mathrm{~cm}$ & 0 & $0.54 \mathrm{~cm} \mathrm{~s}^{-1}$ & 1.25 \\
\hline $\begin{array}{l}\text { Blenny } \\
\text { Lipophrys pholis }\end{array}$ & 203 & 13 & $27.2 \mathrm{~s}$ & $47.7 \mathrm{~cm}$ & 0.30 & $1.36 \mathrm{~cm} \mathrm{~s}^{-1}$ & 1.31 \\
\hline $\begin{array}{l}\text { Scorpion fish } \\
\text { Taurulus bubalis }\end{array}$ & 12 & 12 & $59.8 \mathrm{~s}$ & $40.9 \mathrm{~cm}$ & 0.52 & $0.42 \mathrm{~cm} \mathrm{~s}^{-1}$ & 1.36 \\
\hline \multirow{2}{*}{$\begin{array}{l}\text { Kruskall-Wallis } \\
\text { chi-square }\end{array}$} & \multirow[t]{2}{*}{$d f=2$} & 4.59 & 37.58 & 1.50 & 25.06 & 71.79 & 4.63 \\
\hline & & 0.101 & $<0.001$ & 0.472 & $<0.001$ & $<0.001$ & 0.099 \\
\hline
\end{tabular}


(a) Lipophrys pholis

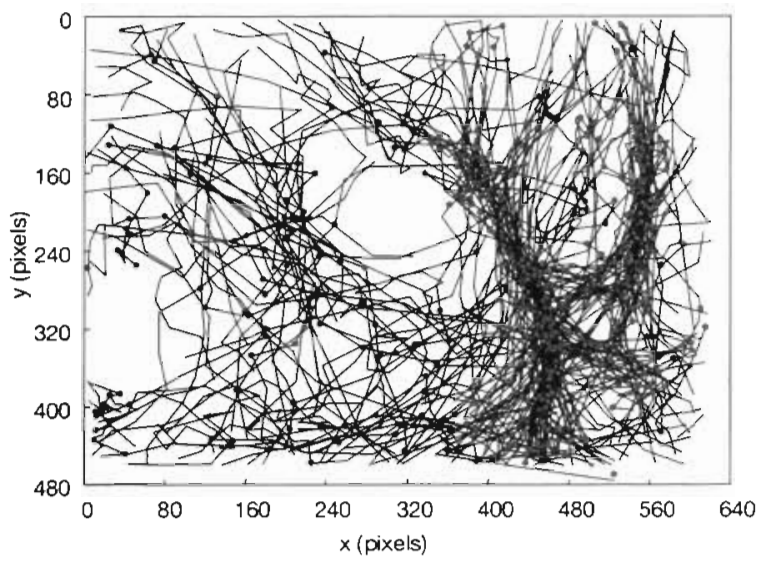

(c) Carcinus maenas

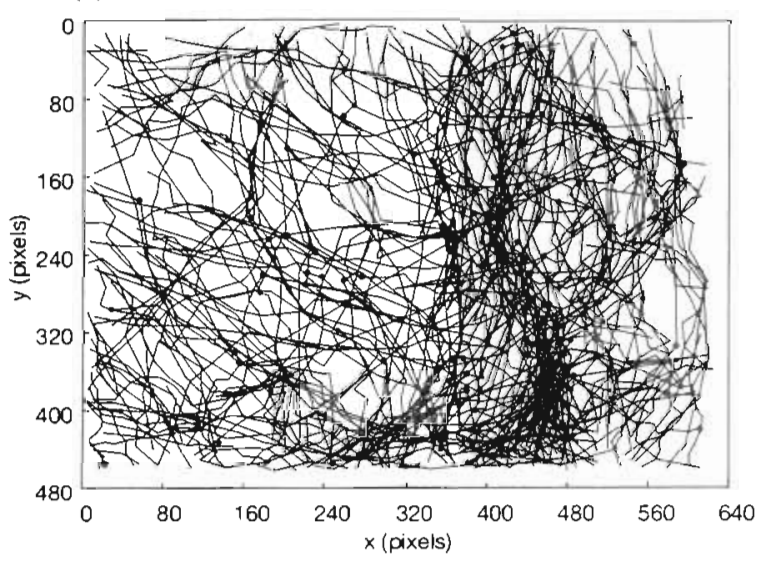

(e) Taurulus bubalis

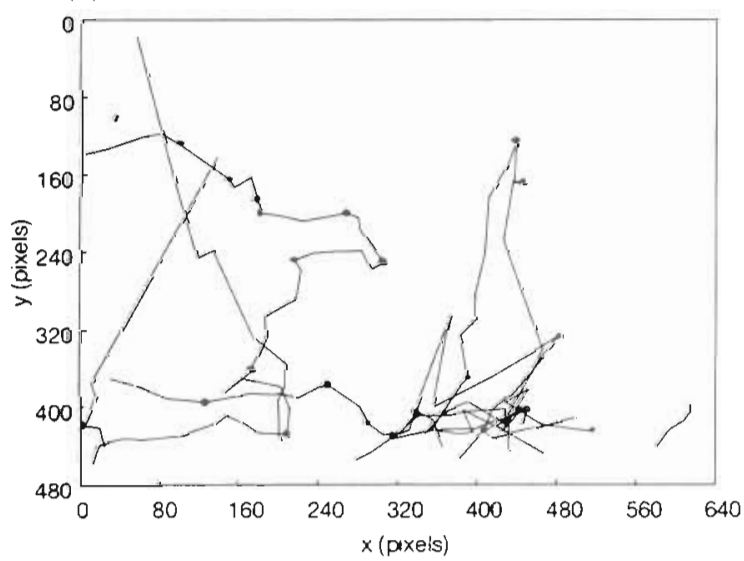

(b)

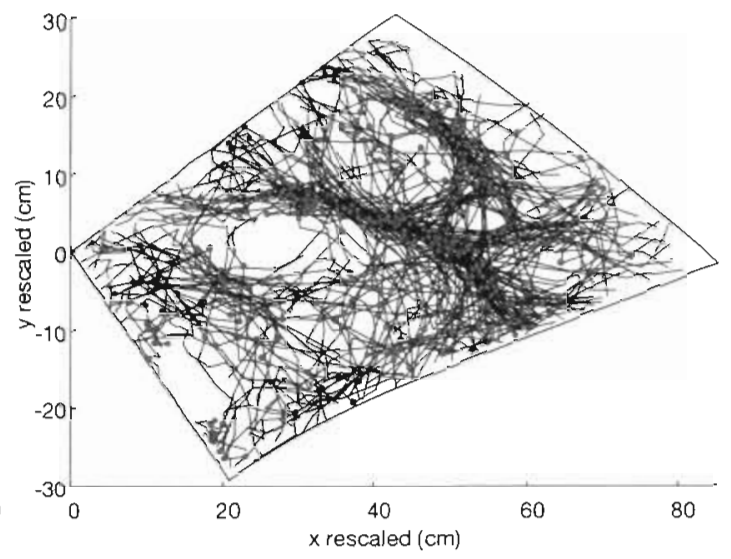

(d)
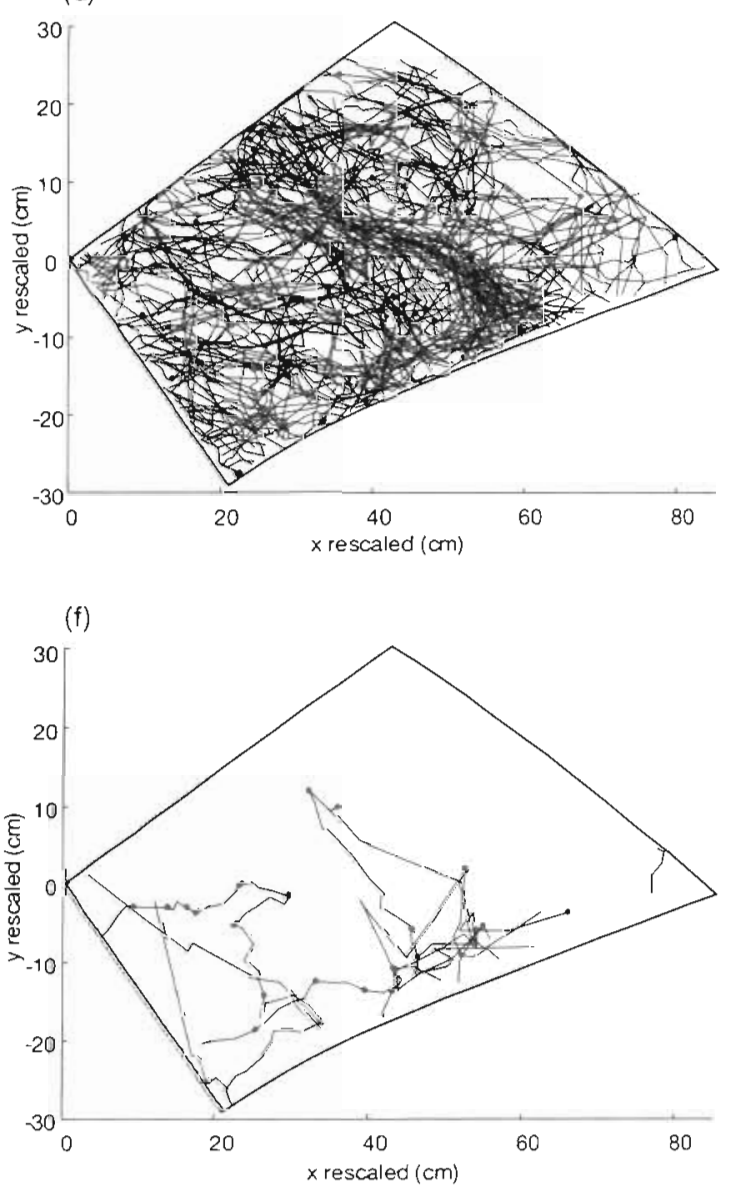

Fig. 3. Observed tracks of $(a, b)$ Lipophrys pholis $(n=203$ sequences $),(c, d)$ Carcinus maenas $(n=193)$ and $(e, f)$ Taurulus bubalis $(n=12)$ as $(a, c, e)$ originally measured and $(b, d, f)$ after scaling and rotation. Circles show locations of pauses

similar distance between 1 and $10 \mathrm{~cm}$ were recorded for all 3 species (Fig. 4a). Average duration of moves by crabs and scorpion fish (3.2 s and $3.0 \mathrm{~s}$ ) were longer than those of blennies (1.0 s, Fig. 5). Duration of pauses followed a similar pattern, with crabs and scorpion fishes having longer stationary pauses on average (34 and $39 \mathrm{~s}$ ) than blennies ( $7 \mathrm{~s}$ average). Moves of blennies averaged a speed of $3.4 \mathrm{~cm} \mathrm{~s}^{-1}$, and those of scorpion fish $2.8 \mathrm{~cm} \mathrm{~s}^{-1}$, while crabs reached only a quarter of the average speed of blennies at $0.8 \mathrm{~cm} \mathrm{~s}^{-1}$. Summary statistics for whole sequences showed similar differences among the 3 species to individual 

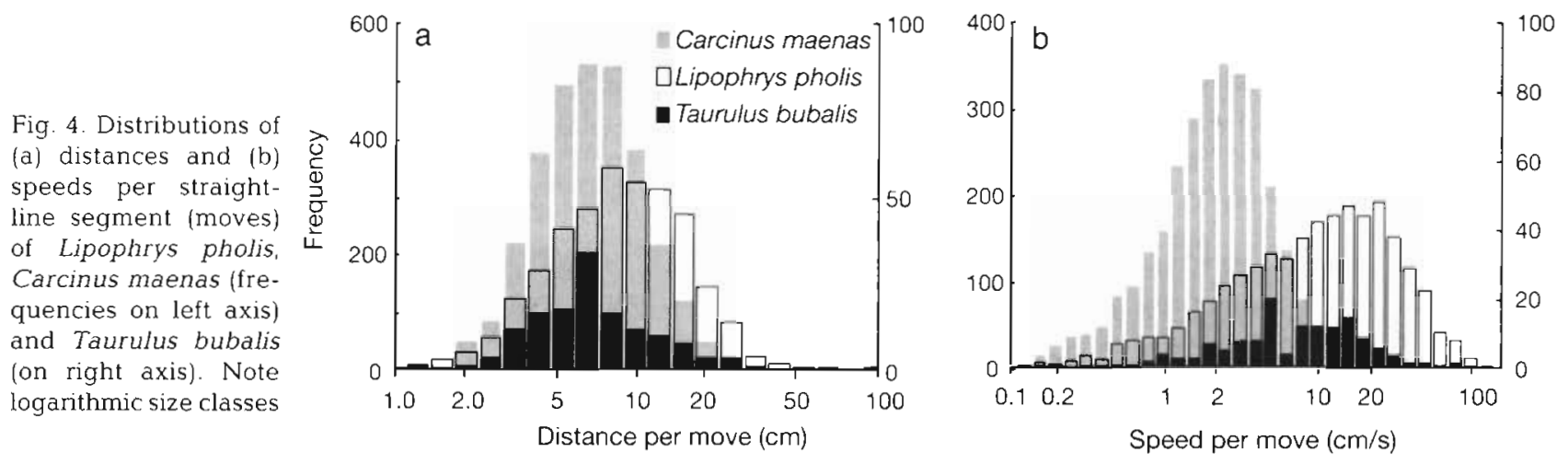

moves (Table 1). While the distance covered, the number of moves and the convolution of the path taken were similar, Lipophrys pholis traversed the screen in less than half the time and at more than twice the speed of Carcinus maenas and Taurulus bubalis. Although the median proportion of time paused was zero for $C$. maenas, crabs spent a long time paused in many sequences giving a mean proportion paused of 0.19 .

Despite the significance of the differences between the species, each showed considerable variation among sequences. Duration, distance travelled, and speed, for example, varied over several orders of magnitude in each species (Fig. 6). The various measures of movement were strongly inter-correlated within each species (Table 2). For Lipophrys pholis and Carcinus maenas the number of moves, total duration and distance travelled, the proportion of time stationary and the convolution of the sequence were all positively correlated with each other. Average speed was negatively correlated with all the other measures. Sequences therefore varied from long convoluted tracks with many pauses at low speed to short direct tracks with few pauses at high speed.
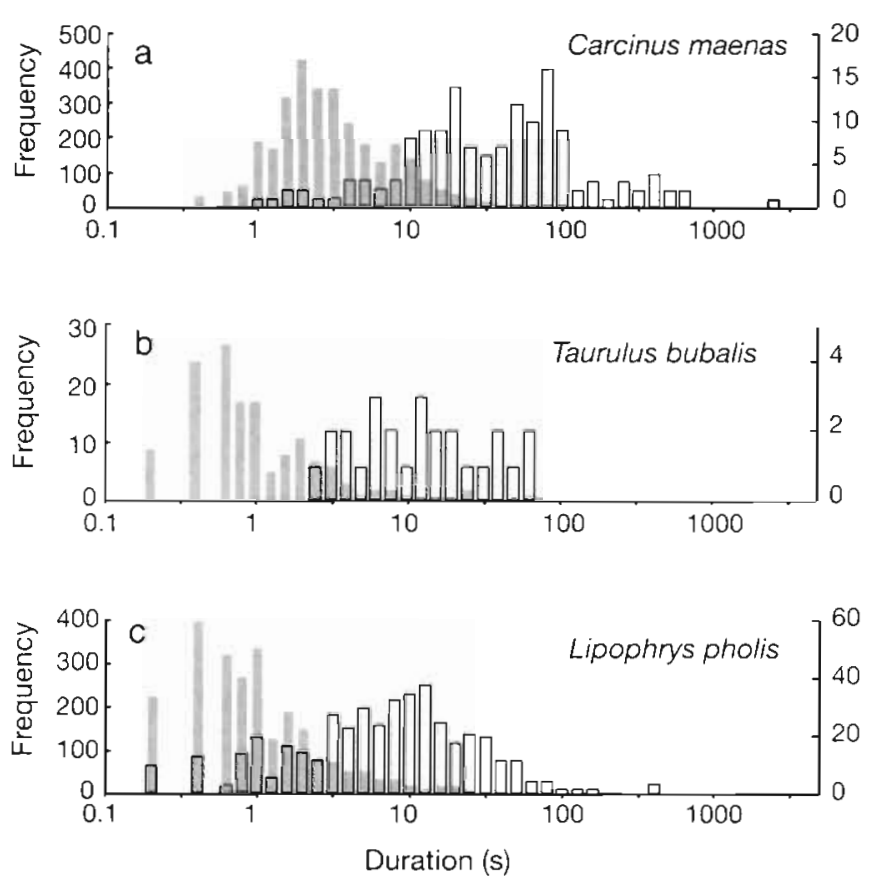

Fig. 5. Distributions of duration of moves (grey bars, frequencies on left axis) and stationary pauses (open bars, frequencies on right axis) of (a) Carcinus maenas, (b) Taurulus bubalis and (c) Lipophrys pholis. Note logarithmic size classes

\section{Temporal patterns in behaviour}

Frequency of occurrence and measures of behaviour of whole sequences were compared for each species among different dates, hours of the day 100:00 to $23: 00 \mathrm{~h}$ ) and time in hours relative to the nearest high water $(6 \mathrm{~h}$ before to $6 \mathrm{~h}$ after high water). On the $7 \mathrm{~d}$ of continuous observation shore crabs were 2 to 4 times as frequent at night as by day (Fig. 7), while blennies were almost never seen
Table 2. Correlations among behavioural measures for sequences of movements of blennies Lipophrys pholis $(\mathrm{n}=203$ ) above the diagonal, and shore crabs Carcinus maenas $(\mathrm{n}=199$ ) below the diagonal. Values shown are Kendall's rank correlation coefficients. All correlations were significant at $p<0.0001$ (with a single exception shown in parentheses)

\begin{tabular}{|c|c|c|c|c|c|c|}
\hline & $\begin{array}{l}\text { No. of } \\
\text { moves }\end{array}$ & $\begin{array}{l}\text { Convo- } \\
\text { lution }\end{array}$ & Distance & Duration & Speed & $\begin{array}{l}\text { Pn time } \\
\text { paused }\end{array}$ \\
\hline No. of moves & - & +0.28 & +0.57 & +0.44 & -0.23 & +0.27 \\
\hline Convolution & +0.33 & - & +0.21 & +0.27 & -0.25 & $(0.04)$ \\
\hline Distance & +0.64 & +0.39 & - & +0.44 & -0.18 & +0.15 \\
\hline Duration & +0.46 & +0.34 & +0.49 & - & -0.74 & +0.38 \\
\hline Speed & -0.21 & -0.20 & -0.19 & -0.70 & - & -0.36 \\
\hline Pn time paused & +0.34 & +0.20 & +0.24 & +0.39 & -0.34 & - \\
\hline
\end{tabular}



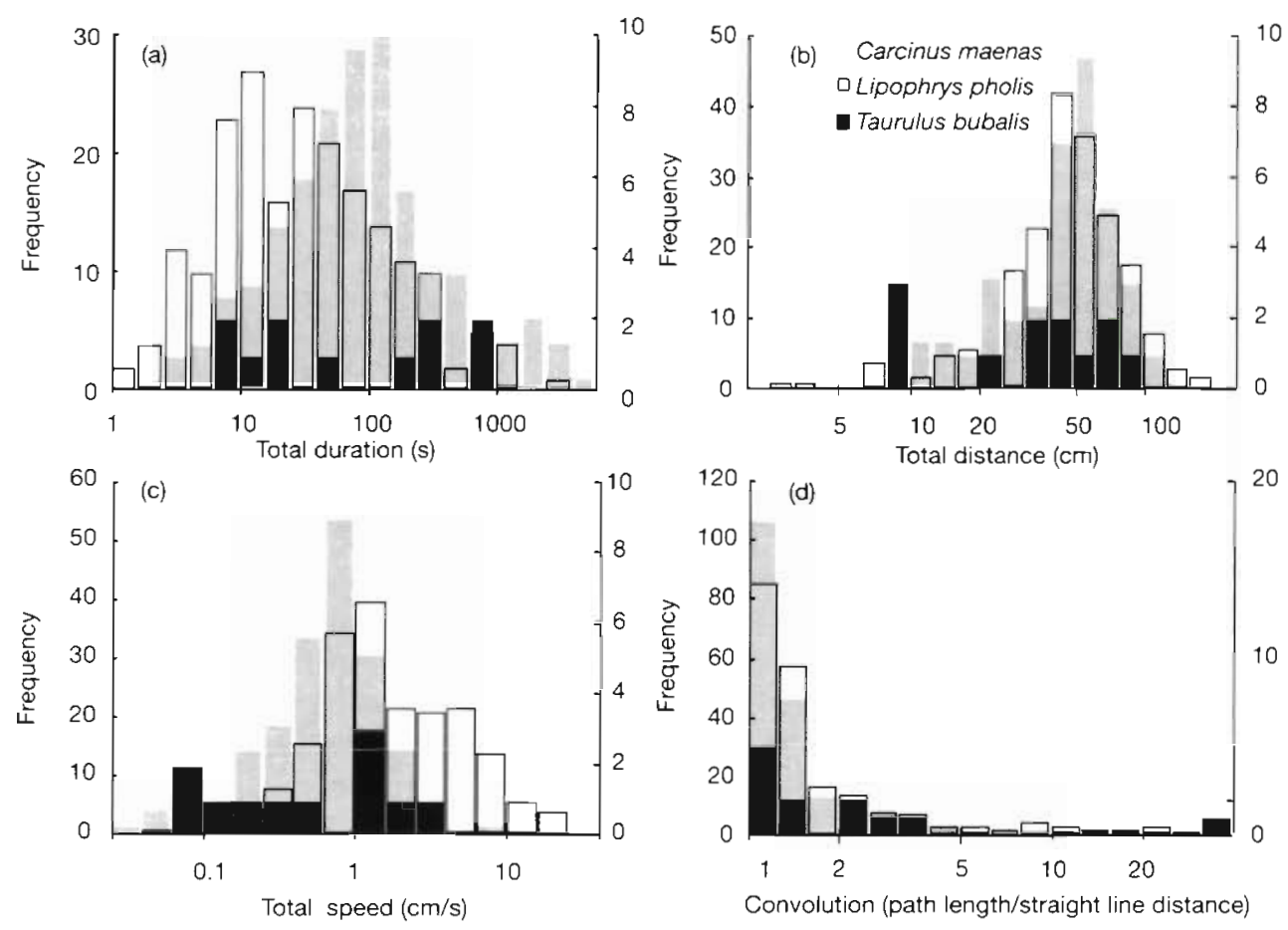

Fig. 6. Measures of entire sequences of moves of Carcinus maenas, Taurulus bubalis and Lipophrys pholis: distributions of (a) total duration, (b) total distance moved, (c) average speed and (d) convolution of the track followed. Frequencies for $T$ bubalis are shown on the right axis

Table 3. Comparison of measures of sequences and frequency of observation among dates, times of day and time relative to high water (Time high water). Data shown are probabilities of Kruskall Wallis $H$-statistics from analyses of variance of ranked data (Zar 1984). Probabilities greater than 0.05 are not shown (ns)

\begin{tabular}{|c|c|c|c|c|c|c|c|}
\hline & Date & $\begin{array}{c}\text { Time } \\
\text { of day } \\
\text { (h) }\end{array}$ & $\begin{array}{l}\text { Time high } \\
\text { water } \\
\text { (h) }\end{array}$ & $\begin{array}{l}\overline{A M} \\
\text { vs } \\
P M\end{array}$ & $\begin{array}{l}\text { Contrast } \\
\text { Night } \\
\text { vs } \\
\text { Day }\end{array}$ & $\begin{array}{l}\text { Ebb } \\
\text { vs } \\
\text { Flood }\end{array}$ & Total df \\
\hline \multicolumn{8}{|l|}{ Carcinus maenas } \\
\hline $\mathrm{df}$ & 8 & 23 & 10 & 1 & 1 & 1 & \\
\hline Distance & ns & ns & ns & ns & ns & ns & 191 \\
\hline Duration & ns & ns & ns & ns & 0.049 & ns & 191 \\
\hline Speed & 0.018 & ns & ns & ns & 0.002 & ns & 191 \\
\hline Convolution & ns & $\mathrm{ns}$ & ns & 0.038 & ns & ns & 191 \\
\hline Pn time paused & ns & ns & ns & ns & ns & ns & 191 \\
\hline $\mathrm{df}$ & 9 & 23 & 11 & 1 & 1 & 1 & \\
\hline $\begin{array}{l}\text { Frequency of } \\
\text { observation }\end{array}$ & 0.014 & 0.024 & ns & 0.002 & 0.001 & ns & 96 \\
\hline \multicolumn{8}{|l|}{ Lipophrys pholis } \\
\hline df & 8 & 17 & 9 & 1 & & 1 & \\
\hline Distance & ns & ns & ns & ns & & ns & 202 \\
\hline Duration & ns & 0.008 & ns & 0.008 & & ns & 202 \\
\hline Speed & ns & 0.036 & ns & 0.010 & & ns & 202 \\
\hline Convolution & 0.018 & ns & 0.033 & ns & & ns & 202 \\
\hline Pn time paused & ns & ns & ns & ns & & ns & 202 \\
\hline $\mathrm{df}$ & 9 & 23 & 11 & 1 & 1 & 1 & \\
\hline $\begin{array}{l}\text { Frequency of } \\
\text { observation }\end{array}$ & ns & 0.001 & ns & 0.050 & 0.001 & ns & 96 \\
\hline
\end{tabular}

during the hours of darkness (21:00 to 04:00 h). Differences in frequency between night and day were highly significant in both species (Table 3). More crabs and fewer blennies were seen between midnight and midday than between midday and midnight. Crabs and blennies were never observed during periods of emersion (from $6 \mathrm{~h}$ before to $6 \mathrm{~h}$ after highwater), but were seen in similar numbers throughout the period of immersion (Fig. 7).

Changes in behaviour among dates and times were seen. Carcinus maenas moved more rapidly on the first 4 days of observation than on the next 3 (Fig. 8e), and more slowly over a longer period during daylight hours than at night (Fig. 8a, c, Table 3, significant Date effect and Night vs Day contrasts). Lipophrys pholis moved more slowly and spent longer in view during the morning than in the afternoon and evening (Fig. 8a, c). L. pholis also tended to move along more convoluted paths before rather than after the time of high water (Fig. 8b). Although the comparison of means was not significant at the 0.05 level, 
Fig. 7 Average frequencies of Carcinus maenas (……) and Lipophrys pholis (-•-) seen (a) during tidal immersion per hour of the day ( $n=5$ per hour) and (b) per hour relative to the time of the nearest high water $(n=13$ per hour for hours -3 to +3 )
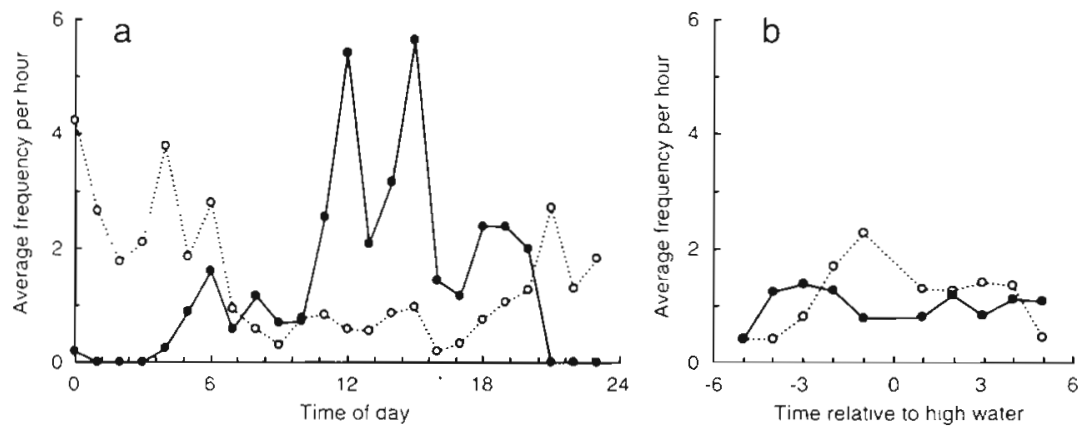

the proportion of time spent paused by blennies was correlated with the hour of the tidal cycle (Kendall's tau $b=-0.157, n=203, p=0.003$ ). Blennies spent $a$ greater proportion of time stationary on the flood tide (0.4 to 0.5$)$ than on the late ebb tide $(0.1$ to 0.2$)$ (Fig. 8b). Both species showed similar changes in convolution of the track among dates (Fig. 8f), with the exception of $L$. pholis on 2 September 1997 (based on only 7 sequences). Most convoluted paths were seen on neap tides.

\section{Spatial patterns in behaviour}

Plots of all the trajectories of the 3 species reveal striking patterns of the use of different areas in the field of view of the camera (Fig. 3). Movements of Lipophrys pholis were concentrated in the regions of surface indentations to the right-hand side of the visible area (compare Fig. 3b and Fig. 2c, h). Fishes followed the lines of these concavities as pathways through the field of view, pausing frequently while
Fig. 8. Changes in behaviour of Carcinus maenas $(\cdots 0 \cdots)$ and Lipophrys pholis (- -) on 3 time scales. (a) Changes in duration of sequences in relation to time of day: lines show significant differences in averages between night and day periods for C. maenas (......, Table 3 ) and between morning and afternoon for $L$. pholis (-). (b) Average proportion of time spent paused versus time relative to high water. (c) Average speed of sequences per hour of the day. (d) Changes in average convolution of the path relative to time in the tidal cycle. (e) Average speed versus date of observation $(\mathrm{d} / \mathrm{mo} / \mathrm{yr})$, and ( $\mathrm{f}$ ) average convolution of the path versus date $(\mathrm{d} / \mathrm{mo} / \mathrm{yr})$, with associated changes in height of high and low water (-+-)
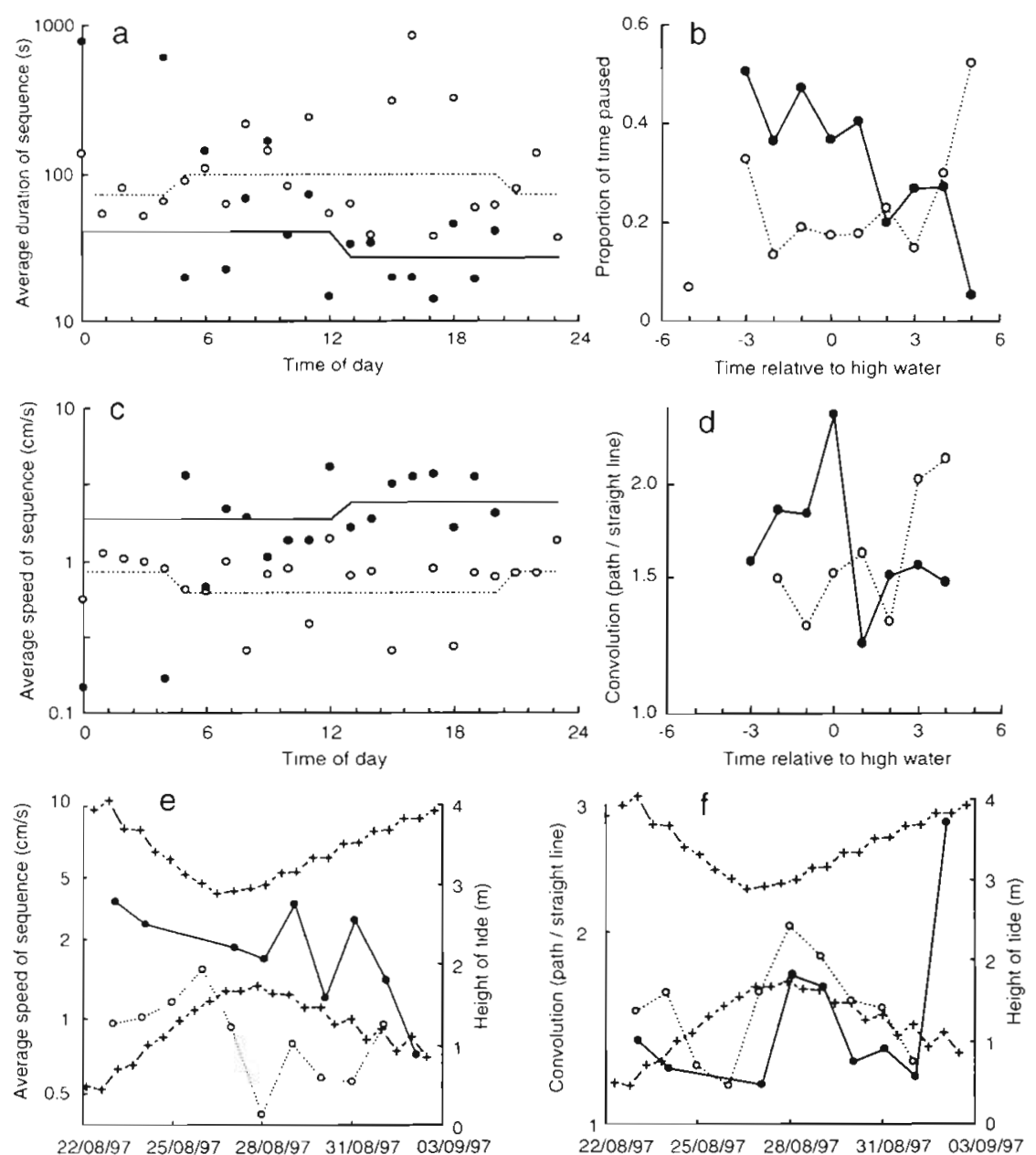

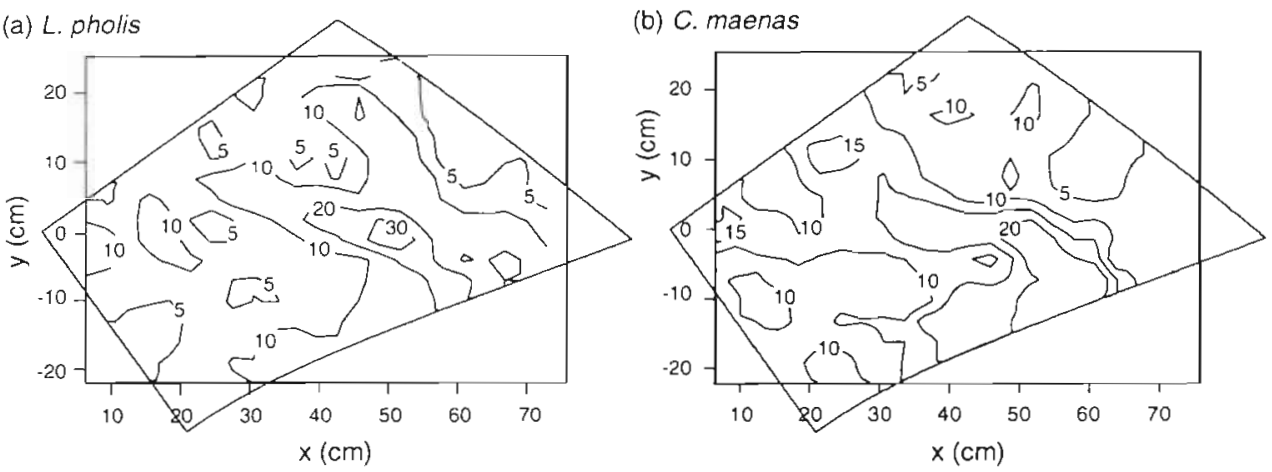

Fig. 9. Contour plots of numbers of visits by (a) Lipophrys pholis and (b) Carcinus maenas to $10 \mathrm{~cm}^{2}$ areas within the video frame. Visits were counted as the number of entries into each cell over the entire period of observation $(7 \mathrm{~d})$ moving along the paths. Convex surfaces below left of these concavities were visited much less often. Movements of Carcinus maenas were less concentrated than those of $L$. pholis but were still more frequent in concave than in convex regions

Spatial patterns of behaviour were analysed by imposition of a square grid of 16 cells vertically by 23 cells horizontally on the field of view as translated into centimetre co-ordinates. Each grid cell measured $3.16 \mathrm{~cm}$ along the side enclosing an area of $10 \mathrm{~cm}^{2}$. Cells including any area outside of the field of view of the camera were excluded from further analysis, yield-

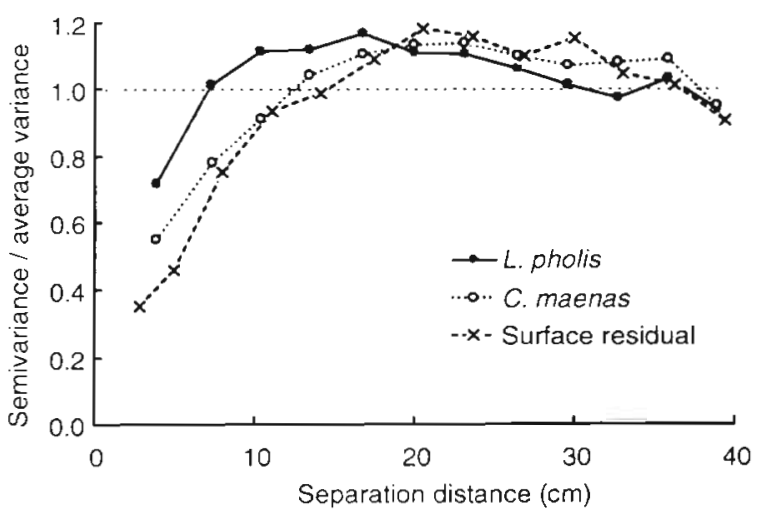

Fig. 10. Semi-variograms of numbers of visits to $10 \mathrm{~cm}^{2}$ areas for Lipophrys pholis and Carcinus maenas (from Fig. 10) and residuals from the fitted response surface for the whole rock surface (small-scale topography: Fig. $2 \mathrm{~h}$ ). Variance was calculated for all pairs of data separated by the distance on the $x$ axis. The plot shows the variance for each separation distance scaled to the whole variance for the area ing a total of 184 cells for the whole area $\left(0.184 \mathrm{~m}^{2}\right)$. The number of moves, the number of separate visits, the total time observed, average distance travelled and proportion of time spent paused were calculated for each cell. The average duration of each visit was also calculated. Gridded data were used to produce contour plots for counts of visits by Lipophrys pholis and Carcinus maenas (Fig. 9). The regions of high frequencies of visits by $L$. pholis showed a branched structure corresponding to the layout of concave areas. C. maenas were seen more frequently in some areas where $L$. pholis were common although the frequented area lacked the branches of that species. The spatial structure of the pattern of visits can also be shown by isotropic variograms (Fig. 10, Rossi et al. 1992). These plots show the variance among all pairs of cells separated by specified distances ('semivariance'). For counts of $L$. pholis the semivariance approached the average variance for cells separated by $7.8 \mathrm{~cm}$, while for $C$. maenas this condition was not reached until cells were separated by 13 to $15 \mathrm{~cm}$. This difference suggests that spatial pattern of counts is more fine-grained in L. pholis.

While the average number of visits per $10 \mathrm{~cm}^{2}$ was similar for both species at 9.9 for Lipophrys pholis and 10.8 for Carcinus maenas, counts of the former were much more variable (variance, $s^{2}=64.9$ ) than the latter $\left(s^{2}=34.0\right)$. Counts of both species had variance to mean ratios far greater than 1 , indicating highly clumped or contagious distributions. A larger proportion of area was visited infrequently by $L$. pholis than by C. maenas (Fig. 11). $80 \%$ of all the time that speci-
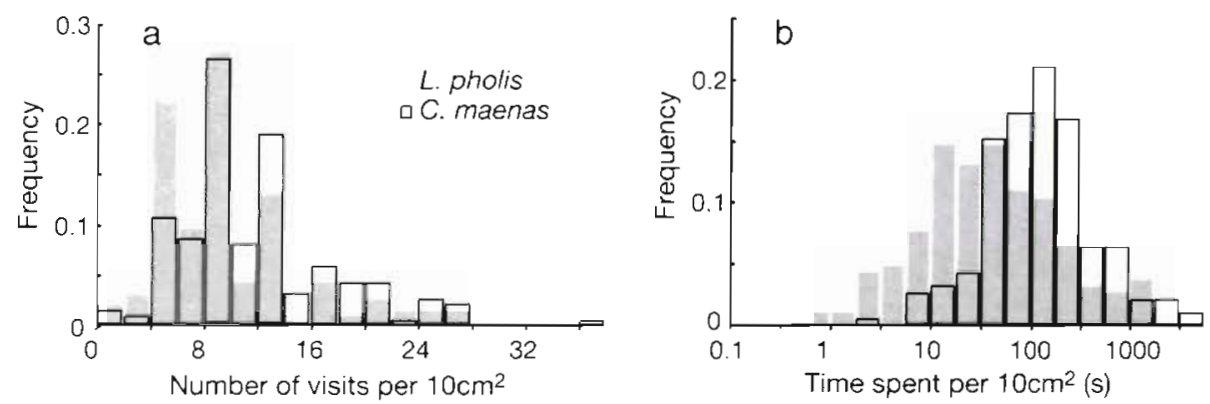

Fig. 11. Frequency distributions of (a) the number of visits to $10 \mathrm{~cm}^{2}$ areas and (b) the total time spent in each area by Lipophrys pholis (grey bars) and Carcinus maenas (open bars) 
Table 4. Correlations among behavioural measures in $10 \mathrm{~cm}^{2}$ regions for blennies Lipophrys pholis $(\mathrm{n}=182)$ above the diagonal, and shore crabs Carcinus maenas $(\mathrm{n}=184$ ) below the diagonal. Values shown are Kendall's rank correlation coefficients. All correlations shown were significant at $\mathrm{p}<0.0001$

\begin{tabular}{|lccccccc|}
\hline & $\begin{array}{c}\text { No. of } \\
\text { visits }\end{array}$ & $\begin{array}{c}\text { No. of } \\
\text { moves }\end{array}$ & $\begin{array}{c}\text { Total } \\
\text { duration }\end{array}$ & $\begin{array}{c}\text { Duration } \\
\text { per visit }\end{array}$ & $\begin{array}{c}\text { Average move } \\
\text { duration }\end{array}$ & $\begin{array}{c}\text { Pn time } \\
\text { paused }\end{array}$ & $\begin{array}{c}\text { Average dis- } \\
\text { tance moved }\end{array}$ \\
\hline No. of visits & - & +0.84 & +0.57 & +0.34 & +0.19 & +0.27 & $\mathrm{~ns}$ \\
No. of moves & +0.85 & - & +0.61 & +0.40 & +0.24 & +0.36 & $\mathrm{~ns}$ \\
Total duration & +0.49 & +0.52 & - & +0.78 & +0.55 & +0.37 & $\mathrm{~ns}$ \\
Duration per visit & +0.18 & +0.23 & +0.70 & - & +0.68 & +0.39 & $\mathrm{~ns}$ \\
Average move duration & +0.08 & $\mathrm{~ns}$ & +0.41 & +0.55 & - & +0.36 & $\mathrm{~ns}$ \\
Pn time paused & +0.24 & +0.29 & +0.42 & +0.43 & +0.24 & $\mathrm{~ns}$ \\
Average distance moved & $\mathrm{ns}$ & -0.22 & $\mathrm{~ns}$ & $\mathrm{~ns}$ & $\mathrm{~ns}$ & $\mathrm{~ns}$ \\
\hline
\end{tabular}

mens of $L$. pholis were observed occurred in $20.9 \%$ of the total area. The same proportion of total time observed for C. maenas occurred in $31.5 \%$ of the area.

Most measures of behaviour were positively correlated with the number of visits to each grid cell (Table 4). While several of these measures were necessarily inter-linked (number of visits, total duration of visits, average duration), others revealed differences in behaviour among regions. Only average distance travelled was not correlated with any other measure. Magnitude and sign of correlations were generally similar in the 2 species. Fishes and crabs spent more time per visit, a greater proportion of time paused and had more prolonged moves (and were therefore slower) in those cells visited more frequently.

\section{DISCUSSION}

Diving during periods of inundation (Palmer 1984, Robles 1987, Robles \& Robb 1993) has previously produced direct observations of movements of mobile predators on rocky shores. The fixed UWTV used in this study has several advantages over diving observations. Animals are less likely to be disturbed by the method of observation. Prolonged observation by day and night and during tide-in and tide-out periods allows determination of diel and tidal patterns of foraging and permits observation of rare but potentially important predatory interactions. A rigid platform and permanent record makes measurement of movements comparatively simple. Compared to a freeswimming observer, the main disadvantage of fixed UWTV is the limits to the field of view and resolution of the image. The other major limitation of UWTV, as used in this study, is that the effort required to produce this level of detail prevents extensive replication, and thereby limits the generality of any conclusions reached.
The intensity of activity of predators other than Nucella lapillus was striking. Up to 4 visits by crabs Carcinus maenas and up to 6 visits by blennies Lipophrys pholis were seen per hour on average. The frequency of visits reflects both activity and abundance of the predators. Single animals may revisit the area several times a day. For the potential prey, the risk of mortality must increase with the frequency of predator visits.

Movements of the 2 species were strongly aligned with surface topography, in line with the primary hypothesis that thigmotaxis of benthic predators would result in concentration of foraging around crevices. Blennies were active only during hours of daylight, like many other species of fishes in intertidal areas (blenniids, Wirtz 1978; labrids, Edwards et al. 1982). The fishes followed regular pathways along the lines of surface depressions (also seen in Coryphoblennius galerita L., Almada et al. 1983). Lipophrys pholis, among other blenny species, has a well-developed homing ability (Gibson 1967a). Mature males defend territories around their nests (Almada et al. 1992, Gonçalves \& Almada 1998) and spend most of their time in the immediate vicinity of the nest. Most of the blennies in this study were smaller juveniles and did not show overtly agonistic or territorial behaviour (Gibson 1968). Despite this, it is likely that the main tracks represent learned pathways around areas known to individual fishes. Fishes introduced into novel areas show exploratory behaviour before developing stereotypical routes between topographical features (Almada et al. 1983). The species is even able to learn routes through mazes to the location of food, a process enhanced by the presence of artificial visual cues (Dodd 1998).

Concentration of movements of Lipophrys pholis along concavities and avoidance of highly convex regions suggests that the species may be susceptible to shear during wave action. Well-developed pectoral fins allow the blenny to hold on to the rock and prevent 
dislodgement (Gibson 1982) and thigmotactic swimming may further reduce such risk. Apart from the cost of physical damage (Nursall 1977), displaced animals may be at greater risk and be less able to best exploit areas for which they have no spatial memory (Hughes et al. 1992).

Changes in behaviour, as shown by speed of movement, the convolution of the path followed and the proportion of time stationary, may reflect changes in foraging behaviour. Lipophrys pholis adopted more meandering tracks and were stationary for more time during flood tide than ebb tide. The species was also slower-moving before noon. This type of behaviour may be associated with searching for, orienting towards and attacking barnacle prey since foraging animals often show a greater rate of turning in the presence of prey (Bell 1991). On the flood tide and at the beginning of the day L. pholis may be hungrier and thus stimulated to feed. Carcinus maenas did not show similar changes in behaviour, but were just less active and moving more slowly during hours of daylight. Crabs appeared to continually browse on the barnacles in the dark whereas blennies made a series of attacks on single barnacles involving visual orientation in the light. The scorpion fish Taurulus bubalis is thought to be a 'sit-and-wait' predator (Gibson 1967a), and the pattern of movements with frequent long pauses seen in this study is consistent with this type of foraging. Although $L$. pholis and C. maenas both have endogenous tidal rhythms of activity (Gibson 1967b, Naylor 1985) there were no obvious changes in activity during tide-in periods. Changes in movement patterns from day to day may have been related to the suitability of conditions for foraging. Both species moved over more convoluted tracks at neap tides when a greater proportion of the intertidal prey were continually covered and accessible to predators.

Greater activity of shore crabs at night has been seen on sedimentary shores (Burrows et al. 1994, Gibson et al. 1998). Intertidal migration is a strong component of behaviour in horizontally oriented shores (Hunter \& Naylor 1993, Warman et al. 1993) but there was little evidence for directed movements up or down the vertical rock in this study. The distance to be travelled to retreat to below low water is very short for any intertidal predator on a near vertical shore. Most movements of crabs and blennies were horizontally oriented.

While their importance on tropical rocky shores is undisputed (Menge \& Lubchenco 1981), highly mobile crab and fish predators have been considered to be relatively unimportant as agents structuring communities on temperate rocky shores (Bertness et al. 1981, Menge 1982). Early predator exclusion experiments showed enhanced survival inside cages (e.g. Connell 1961,
1970, Dayton 1971, Menge 1976), with effects often assumed to be due to the obvious and abundant sluggish intertidal residents such as muricid gastropods and starfish. However, close-mesh exclusion cages also prevent access by fishes and crabs (Edwards et al. 1982), leaving the possible effects of the latter untested by the early studies. Later work with a range of cage mesh sizes did demonstrate effects of fishes and crustacea (Menge et al. 1986, Robles 1987, Robles \& Robb 1993). Removals of single and multiple species have been successful in demonstrating unequivocal effects of specific predators (Fairweather et al. 1984), although impacts are often highly variable among different sites (Fairweather \& Underwood 1991).

The study site was less wave-exposed than many other temperate North Atlantic shores. Predation has been found to be more important in sheltered areas (Menge \& Sutherland 1976) and areas of reduced water flow (Leonard et al. 1998), with mobile predators controlled by environmental stress (Menge 1978, Menge \& Sutherland 1987, Burrows \& Hughes 1989). Deployment of video cameras in a variety of conditions of wave exposure could directly test this hypothesis.

Like the early predator exclusion studies, localised impacts of predators around their refuges have similarly been assumed to be due to the predators found in these refuges at low tide, often muricid gastropods. While the low tide occupants of refuges may be responsible for much of the local depletion of prey, this study shows that movements of fishes and crabs are also concentrated in areas used as refuges by gastropods.

Barnacles form the major part of the diet of $L i$ pophrys pholis (Quasim 1957, Milton 1983) and have been found to be part of the diet of Carcinus maenas (Elner 1981). Both species appeared to forage on the dense population of Semibalanus balanoides in the present study. On rocky shores $C$. maenas is better known as a predator of mussels (Kitching \& Ebling 1967, Elner \& Hughes 1978), and may have been foraging for very small littorinids in this study. L. pholis removes barnacle cirri by biting. This may not be fatal to the barnacles. $S$. balanoides can regenerate excised cirri within 3 wk of being attacked (M.T.B. pers. obs.) at an unknown cost in terms of lost opportunity for growth. Although single attacks on prey were not located in this study, areas of foraging form a subset of the total area where the predators were seen. Of the 2 species, $L$. pholis made movements that were more concentrated around crevices, has a diet comprised mainly of barnacles and is therefore the most likely to generate spatially localised depletion of prey. Smallscale surveys of the incidence of damaged or missing cirri in barnacles around crevices and direct observation of patterns of attacks would be very useful 
Acknowledgements. K.K and R.N.H. were supported by E.U grant MAS3-CT95-0012 (EUROROCK) and a NERC Special Topic grant GST/02/983. We would like to thank Linda Robb for help with video analysis and Jane Dodd and anonymous referees for their helpful comments.

\section{LITERATURE CITED}

Almada V, Dores J, Pinheiro M, Santos RS (1983) Contribuiçao para o estudo do comportamento de Coryphoblennius galerita (L.) (Pisces: Blenniidae). Mem Mus Mar Ser Zool 2:1-166

Almada VC, Gonçalves EJ, Oliveira RF, Barata EN (1992) Some features of the territories in the breeding males of the intertidal blenny Lipophrys pholis (Pisces, Blenniidae) J Mar Biol Assoc UK 72:187-197

Archambault P, Bourget E (1996) Scales of coastal heterogeneity and benthic intertidal species richness, diversity and abundance. Mar Ecol Prog Ser 136:111-121

Bell WJ (1991) Searching behaviour: the behavioural ecology of finding resources. Chapman and Hall, London

Bertness MD, Garrity SD, Levings SC (1981) Predation pressure and gastropod foraging: a tropical-temperate comparison. Evolution 35:995-1007

Burrows MT, Hawkins SJ (1998) Modelling patch dynamics on rocky shores using deterministic cellular automata. Mar Ecol Prog Ser 167:1-13

Burrows MT, Hughes RN (1989) Natural foraging of the dogwhelk. Nucella lapillus (L.): the weather and whether to feed. J Molluscan Stud 55:285-295

Burrows MT, Gibson RN, Robb L, Comely CA (1994) Temporal patterns of movement in juvenile flatfishes and their predators: underwater television observations. I Exp Mar Biol Ecol 177:251-268

Connell JH (1961) Effect of competition, predation by Thais lapillus, and other factors on natural populations of the barnacle Balanus balanoides. Ecol Monogr 31:61-104

Connell JH (1970) A predator-prey system in the marine intertidal region. I. Balanus glandula and several species of Thais. Ecol Monogr 40:49-78

Craik C (1997) Long-term effects of North American Mink Mustela vison on seabirds in western Scotland. Bird Study 44:303-309

Crisp DJ, Meadows PS (1962) The chemical basis of gregariousness in cirripedes. Proc R Soc Lond B 156:500-520

Dayton PK (1971) Competition, disturbance and community organisation: the provision and subsequent utilisation of the space in a rocky intertidal community. Ecol Monogr 41:351-389

Dodd J (1998) Topographic learning and memory in habitat selection by Lipophrys pholis L. PhD thesis, University of Wales, Bangor

Dunkin SDB, Hughes RN (1984) Behavioural components of prey-selection by dogwhelks, Nucella lapillus (L.), feeding on barnacles, Semibalanus balanoides (L.), in the laboratory. J Exp Mar Biol Ecol 79:91-103

Edwards DC, Conover DO, Sutter F III (1982) Mobile predators and the structure of marine intertidal communities. Ecology 63:1175-1180

Elner RW (1981) Diet of green crab, Carcinus maenas (L.) from Port Hebert, southwestern Nova Scotia. J Shellfish Res 1:89-94

Elner RW, Hughes RN (1978) Energy maximisation in the diet of the shore crab, Carcinus maenas (L.). J Anim Ecol 47: $103-116$

Emlen JL (1966) Time, energy and risk in two species of car- nivorous gastropods. PhD thesis. University of Washington, Seattle

Fairweather PG (1988) Predation creates haloes of bare space among prey on rocky seashores in New South Wales. Aust J Ecol 13:401-409

Fairweather PG, Underwood AJ (1991) Experimental removals of a rocky intertidal predator: variations within two habitats in the effects on prey. J Exp Mar Biol Ecol $154: 29-75$

Fairweather PG, Underwood A.J, Moran MJ (1984) Preliminary investigations of predation by the whelk Morula marginalba. Mar Ecol Prog Ser 17:143-156

Fischer-Piette E (1935) Histoire d'une moulière. Observations sur une phase de déséquilibre faunique. Bull Biol Fr Belg 5:153-177

Gibson R (1967a) Studies on the movements of littoral fish J Anim Ecol 35:215-234

Gibson RN (1967b) Experiments on the tidal rhythm of Blennius pholis. J Mar Biol Assoc UK 47:97-111

Gibson RN (1968) The agonistic behaviour of juvenile Blennius pholis L. (Teleostei). Behaviour 30:192-217

Gibson RN (1982) Recent studies on the biology of intertidal fishes. Oceanogr Mar Biol Annu Rev 20:363-414

Gibson RN, Pihl L, Burrows MT, Modin J, Wennhage H, Nickell LA (1998) Diel movements of juvenile plaice Pleuronectes platessa in relation to predators, competitors, food availability and abiotic factors on a microtidal nursery ground. Mar Ecol Prog Ser 165:145-159

Gonçalves EJ, Almada VC (1998) A comparative study of territoriality in intertidal and subtidal blennioids. Environ Biol Fishes 51:257-264

Hartnoll RG, Hawkins SJ (1985) Patchiness and fluctuations on moderately exposed rocky shores. Ophelia 24:53-63

Hughes RN, Burrows MT (1993) Predatory behaviour of the intertidal snail, Nucella lapillus and its effects on community structure. In: Kawanabe H, Cohen JE, Iwasaki K (eds) Mutualism and community organisation: behavioural, theoretical and food web approaches. Oxford University Press, Oxford, p 63-83

Hughes RN, Kaiser MJ, Mackney PA, Warburton K (1992) Optimizing foraging behaviour through learning. J Fish Biol (Suppl B) 41:77-91

Hunter E, Naylor E (1993) Intertidal migration by the shore crab Carcinus maenas. Mar Ecol Prog Ser 101:131-138

Johnson MP, Burrows MT, Hartnoll RG, Hawkins SJ (1997) Spatial structure on moderately exposed rocky shores: patch scales and the interactions between limpets and algae. Mar Ecol Prog Ser 160:209-215

Johnson MP, Hughes RN, Burrows MT, Hawkins SJ (1998) Beyond the predation halo: small scale gradients in barnacle populations affected by the relative refuge value of crevices. J Exp Mar Biol Ecol 231:163-170

Kitching JA, Ebling FJ (1967) Ecological studies of Lough Ine. Adv Ecol Res 4:198-291

Kostlyev V (1996) Spatial heterogeneity and habitat complexity affecting marine littoral fauna. PhD thesis, Göteborg University

Leonard GH, Levine JM, Schmidt PR, Bertness MD (1998) Flow-driven variation in intertidal community structure in a Maine estuary. Ecology 79:1395-1411

Menge BA (1976) Organisation of the New England rocky intertidal community: role of predation, competition and environmental heterogeneity. Ecol Monogr 46:355-393

Menge BA. (1978) Predation intensity in a rocky intertidal community. Oecologia 34:1-16

Menge BA (1982) Reply to a comment by Edwards, Conover, and Sutter. Ecology 63:1180-1184 
Menge BA, Lubchenco J (1981) Community organisation in temperate and tropical rocky intertidal habitats: prey refuges in relation to consumer pressure gradients. Ecol Monogr 51:429-450

Menge BA, Sutherland JP (1976) Species diversity gradients: synthesis of the roles of predation, competition and spatial heterogeneity. Am Nat 110:351-369

Menge BA, Sutherland JP (1987) Community regulation: variation in disturbance, competition and predation in relation to environmental stress and recruitment. Am Nat 130: $730-757$

Menge BA, Lubchenco $J$, Ashkenas LR, Ramsey F (1986) Experimental separation of effects of consumers on sessile prey in the low zone of a rocky shore in the Bay of Panama: direct and indirect effects of food web complexity. J Exp Mar Biol Ecol 100:225-269

Milton P (1983) Biology of littoral blenniid fishes on the coast of south-west England. J Mar Biol Assoc UK 63:223-237

Naylor E (1985) Tidally rhythmic behaviour of marine animals. Symp Soc Exp Biol 39:69-93

Nursall JR (1977) Territoriality in redlip blennies (Ophioblennius atlanticus - Pisces, Blenniidae). J Zool Lond 182:205-223

Paine RT (1966) Food web complexity and species diversity Am Nat 100:65-75

Paine RT, Levin SA (1981) Intertidal landscapes: disturbance and the dynamics of pattern. Ecol Monogr 51:145-178

Palmer AR (1984) Prey selection by thaidid gastropods: some observational and experimental field tests of foraging models. Oecologia 62:162-172

Quasim SZ (1957) The biology of Blennius pholis L (Teleostei). Proc Zool Soc Lond 128:161-208

Robles C (1987) Predator foraging characteristics and prey

Editorial responsibility: Otto Kinne (Editor),

Oldendorf/Luhe, Germany population structure on a sheltered shore. Ecology 68: $1502-1514$

Robles C, Robb J (1993) Varied carnivore effects and the prevalence of intertidal algal turfs. J Exp Mar Biol Ecol 166:65-91

Rossi RE, Mulla DJ, Journel AG, Franz EH (1992) Geostatistical tools for modeling and interpreting ecological spatial dependence. Ecol Monogr 62:277-314

Seed R (1969) The ecology of Mytilus edulis L. (Lamellibranchiata) on exposed rocky shores. II. Growth and mortality. Oecologia 3:317-350

Shanks AL, Wright W G (1986) Adding teeth to wave action: the destructive effects of wave borne rocks on intertidal organisms. Oecologia 69:420-428

Underwood AJ, Chapman MG (1996) Scales of spatial patterns of distribution of intertidal invertebrates. Oecologia 107:212-224

van Rooj JM, Videler JJ (1996) A simple method for stereophotographic length measurement of free swimming fish: merits and constraints. J Exp Mar Biol Ecol 195: $237-249$

Warman CG, Reid DG, Naylor E (1993) Variation in the tidal migratory behaviour and rhythmic light-responsiveness in the shore crab, Carcinus maenas. J Mar Biol Assoc UK 73 : $355-364$

Wethey DS (1984) Sun and shade mediate competition in the barnacles Chthamalus and Semibalanus: a field experiment. Biol Bull (Woods Hole) 167:176-185

Wirtz P (1978) The behaviour of the Mediterranean Tripterygion species (Pisces, Blennoidae). Z Tierpsychol 48: $142-174$

Zar JH (1984) Biostatistical analysis, 2nd edn. Prentice Hall, Englewood Cliffs, NJ

Submitted: October 23, 1998; Accepted: May 14, 1999 Proofs received from author(s): September 27, 1999 